Board roles in organisations with a dual board system: Empirical evidence from

Taiwanese nonprofit sport organisations

Chien Mu Yeh

School of Leisure, Sport and Tourism

University of Technology, Sydney, Australia

Tracy Taylor, PhD

School of Leisure, Sport and Tourism

University of Technology, Sydney, Australia

Russell Hoye, $\mathrm{PhD}$ *

School of Sport, Tourism and Hospitality Management

La Trobe University

Victoria 3086, Australia

Ph: +6139479 1345

Fax: +61394791010

Email: r.hoye@latrobe.edu.au

* Corresponding author 


\title{
Board roles in organisations with a dual board system: Empirical evidence from Taiwanese nonprofit sport organisations
}

\begin{abstract}
Research on the roles of the board of unitary board systems is well established, while explorations of dual board systems are very limited. We know little about nonprofit sport organisations board roles in countries, such as Taiwan, that operate with a board dual structure. In consequence, this study explored the roles taken by the board of directors and the board of supervisors in Taiwanese nonprofit sport organisations. Four overarching board of director roles were identified: manage vision and purpose; board duty; human resource and fundraising; and stakeholder focus. For the board of supervisors two primary functions emerged: monitoring results; and board duty and process. The findings of the study extend our understanding of the governance of nonprofit sport organisations and the differences that exists between dual board and single board systems of governance.
\end{abstract}


Identifying the role of boards that govern nonprofit sport organisations has attracted an increasing amount of attention from a number of researchers (Ferkins et al., 2005; Forster, 2006; Hoye \& Cuskelly, 2007; Inglis, 1997; Shilbury, 2001). The role that government funding agencies believe these boards should fulfil has also been articulated in various statements of governance principles and guidelines (Australian Sports Commission, 2002; 2005; Sport and Recreation New Zealand (SPARC), 2004; 2007; UK Sport, 2004). These research efforts and guidelines have, however, been primarily focused on boards that operate within single tier board systems.

Outside of the nonprofit sport sector, there is also a significant body of research into the roles of individual board members in for-profit organisations (Dulewicz and Herbert, 1999; Kula, 2005; Jonsson, 2005; Johnson et al., 1996; Long et al., 2005; McNulty \& Pettigrew, 1999; Van den Heuvel et al., 2006; Zahra \& Pearce, 1989) and other nonprofit organisations (Cornforth, 2001; Cornforth \& Edwards, 1999; Iecovich, 2004; Inglis et al., 1999) that has also focused on boards and board members operating within single tier board systems. The many sets of governance guidelines developed by stock exchanges and corporate regulatory agencies also tend to focus on the single tier board systems, as this is the most common board system in the majority of westernized economies.

There are, however, a number of countries that require the use of dual or two-tier board systems. The board structures adopted by countries such as China, Germany, Japan and the Netherlands are characterised by a two-tier board system composed of a board of directors and a board of supervisors. While research on board roles in these settings has been growing (Bezemer et al., 2007; Cooke \& Sawa, 1998; Dahya et al., 2003; 
Koladkiewicz, 2001; Maassen \& Van den Bosch, 1999; Nietsch, 2005; Rose, 2005; Schilling; 2001; Xiao et al., 2004), few studies have empirically examined board roles in nonprofit organisations that operate with a dual or two-tier board system. Indeed, there is a growing call for conducting research designed to identify the functions and machinations of the board of directors and supervisors in these settings (Dahya et.al., 2003; Turnbull, 1997; Xiao et al., 2004).

Nonprofit Taiwanese sport organisations must utilise a dual board system in which a board of directors and a board of supervisors are provided the same legal status. The purpose of this paper is to present the results of a study that sought to identify the respective roles of the board of directors and the board of supervisors for nonprofit sport organisations operating with a dual board system in Taiwan. In addition, the process of board member selection, the demographic composition of the respective boards and the contribution of each board to the organisation's operations were explored.

The Civil Organisation Law of Taiwan requires all nonprofit organisations to register as a civil organisation under a relevant government body, such as the Ministry of the Interior, and stipulates basic requirements for the establishment, operation and governance of nonprofit organisations, including the adoption of a dual board system. The Civil Organisation Law, however, fails to clearly outline the respective roles of each of these boards, and requires nonprofit organisations to establish their own internal regulations for how these boards should operate. While generic descriptions of the respective roles of boards of directors and boards of supervisors can be found in the internal regulations of Taiwanese nonprofit sport organisations, there is little reported research that has examined the roles that directors and supervisors actually perform in 
this dual board system. The following sections review the literature related to board roles in sport organisations, the dual board system in Taiwan, and relevant research that has been conducted into dual board systems.

\section{Board roles in sport organisations}

Governance has been identified as influential in the performance of sport organisations because of its pivotal role in setting policy and direction for the organisation (Ferkins et al., 2005; Hoye, 2006; Hoye \& Cuskelly, 2007). In a governance system, the board has a critical responsibility of ensuring that the activities of the organisation are carried out in the best interests of the organisation (Australian Sports Commission (ASC), 2005). The importance of governance has been well-recognized by government bodies that fund and support sport organisations and by sport organisations themselves. Several authorities have outlined the parameters of board roles in sport organisations (ASC, 2005; European Olympic Committee, 2001). The ASC (2005, p. 3) identified eleven key roles for the board of a nonprofit sport organisation as:

1. Strategic planning - defining, driving and monitoring the organisation's strategic direction, priorities and results.

2. Stakeholder involvement - defining key relationships, interacting with stakeholders to inform them of achievements and ensuring that stakeholders have input into determining strategic goals and direction.

3. Enhancing the organisation's public image - promoting the organisation in a positive light and performing 'ambassadorial' duties.

4. Organisational performance - reviewing, monitoring and ensuring management and organisational performance. 
5. Reporting - reporting to members and stakeholders at the annual general meeting.

6. Policy formulation - establishing the board-level policy framework for governing the organisation, from which all operational policies and actions are developed.

7. Management of the CEO - appointment, management and review, providing advice and guidance and rewarding the CEO as appropriate.

8. Legal compliance - monitoring organisational compliance with relevant federal, state and local legislation, and the organisation's constitution.

9. Management of financial resources - approving the allocation of funds through the annual budget, striving to secure the resources required and ensuring sound financial management of the organisation.

10. Risk management - ensuring the risks facing the organisation are identified and assessed, ensuring a risk management plan is established, regularly reviewing this plan to ensure its effectiveness and monitoring compliance with it.

11. Board effectiveness - carrying out board business through productive meetings, engaging in regular self-assessment and evaluation, and initiating board development

However, the actual roles performed by the boards of nonprofit sport organisations may not reflect these normative guidelines or principles. Somewhat surprisingly there have only been two significant studies that have explored the roles of sport boards. Inglis's (1997) study of executive directors, board presidents and board members of Canadian nonprofit sport organisations grouped board roles into four factors with 16 items. The four key roles were: 1 . Mission—ethical responsibilities, following charters, and 
keeping policies in line with mission; 2. Planning — financial policy, budget allocations, human resources and long-range plans and strategies; 3.Executive Director-hiring and monitoring of the executive directors as well as concern for fulfilling legal responsibilities; and 4.Community Relations_-developing and delivering specific programs and services, representing the interest of certain groups, raising funds, and promoting advocacy and community relations. Notably, there was a significant difference in the perception of paid staff and board members and male and female members of the importance and performance of board roles.

A study of Australian sport boards found that strategy, developing financial policies, and budgeting were perceived as the most important board roles in sport organisations (Shilbury, 2001). In this study paid staff were found to have influence over issues that were historically the purview of the board (Shilbury, 2001). These empirical investigations of what boards actually do in their sport organisations has provided a basis for current understandings of board roles within nonprofit sport organisations.

\section{Dual boards in Taiwan}

As previously mentioned, the Civil Organisation Law of Taiwan requires nonprofit sport organisations to establish two boards, a board of directors and a board of supervisors (Yeh \& Woidtke, 2005). The status of the board of directors and the board of supervisors are equal (Solomon et al., 2003), and the dual board system is common to both the for-profit and nonprofit sectors in Taiwan. Members of the board of directors and supervisors are volunteers who are elected by the organisation's members. Individual board members can be removed by the general assembly (where all organisational members meet yearly or regularly and have equal representation) if they 
are found violating Taiwanese laws, organisational regulations and/or decisions made by the general assembly (Section 22); or an individual board member can be removed if s/he is voted out by board members (Section 23). The size of the board of directors of civil organisations at the national level is restricted to 35, and the maximum number of the board of supervisors is one-third of the number of the board of directors (Section 17). Figure 1 depicts the most common structural application of the board of directors and the board of supervisors. All members are at the same level within the organisations' structure.

$<$ Insert Figure 1 about here $>$

The dual board system in Taiwan has several distinctive characteristics that differentiate it from two-tier board systems, such as those found in Germany, Demark, Japan, Netherlands, and China. For instance, supervisors in Germany have the power to appoint and remove directors (Bezemer et al., 2007; Schilling; 2001). In Demark, half of the number of supervisors can also be directors. In the dual board system of Taiwanese nonprofit organisations, the directors and supervisors are elected by organisational members. In other words, a director or a supervisor must be an organisational member. However, an organisational member can only be elected as either a director or a supervisor. A director can not be removed by the board of supervisors; this can only be done by the board of directors or the general assembly.

Unlike the Taiwanese situation, where the board of directors and board of supervisors are deemed to have equal status, in China the status of supervisory boards is lower than the board of directors (Dahya et al., 2003; Xiao et al., 2004); while supervisory boards 
in Germany have a higher status than management boards (Solomon et al., 2003). In Japan, the Commercial Code requires a company to have at least one "outside” statutory auditor who is not a director or employee of the company (Cooke \& Sawa, 1998); there is no such requirement in the Civil Organisation Law of Taiwan.

While governance research in Taiwan has been increasing in the last five years (Chen et al., 2007; Filatotchev et al., 2005; Lee \& Yeh, 2004; Solomon et al., 2003; Yeh \& Woidtke, 2005), most of this research has focused on profit oriented corporations. Furthermore, research on supervisory boards has attracted relatively less attention than that on the board of directors. While the Taiwanese for-profit and nonprofit sectors both employ the dual board system, there are some significant differences in board governance. The Company Law stipulates publicly listed companies should have a minimum of two supervisors, but there is no minimum number of supervisors for general companies; and supervisors do not perform like a board but are more akin to individuals that are responsible for independent monitoring (Filatotchev et al., 2005; Solomon et al., 2003). This situation is similar to the function of supervisory boards in Japan (Filatotchev et al., 2005; Solomon et al., 2003). The Civil Organisation Law does stipulate a minimum number of supervisors for each nonprofit organisation, and in nonprofit organisations the board of supervisors must hold regular meetings and perform like a board, rather than as individuals.

\section{Board roles in dual board structures}

In the nonprofit setting, board member roles have been described by several authors (Cadbury, 2002; Carver, 1997; Houle, 1989; Pointer \& Orlikoff, 2002) and include: to determine the organisation's mission and policy; conduct strategic planning; 
monitor/assess programs and services; appoint, monitor, evaluate, reward, replace and work with the executive; ensure that the organisation meets all legal requirements; secure financial resources and manage financial matters; manage the relationship with external environment; and conduct self-appraisals.

An empirical study on board roles by the Charity Commission in England and Wales found that board effectiveness was associated with how well the board conducted five roles, namely: setting the organisation's mission/values; helping raise funds or other resources; overseeing financial management; reviewing/deciding strategic directions; and reviewing board performance (Cornforth, 2001). 'Checking propriety/legality, safeguarding assets/organisational missions, and accounting for expenditure' (Cornforth and Edwards, 1999, p. 360) were recognized as the main roles of nonprofit directors. In research on Israeli nonprofit organisations, board roles were categorised into four factors: human resource management; maintenance of relationship with the task environment; policymaking and fiscal management; and fundraising (Iecovich, 2004).

Inglis et al.’s seminal (1999) study of Canadian nonprofit organisations classified board roles of organisations into three groups: strategic activities; operations; and resource planning. Strategic activities included developing and assessing overall strategies, ensuring mission and vision, setting policies, evaluating the CEO, responding to community needs, developing collaboration and assessing itself. The operations functions included developing and delivering programs and services, advocating interests for certain groups and raising funds .The resource planning included allocating annual budget, hiring senior staff, and setting financial policy. All of these research efforts have been in the context of single tier board systems. 
A number of studies have focused on the board of supervisors in the for-profit sector, including describing the role of supervisors (Cook \& Sawa, 1998), internal and external service of the supervisory board (Bezemer et al., 2007), handling of the supervisory board (Schilling, 2001), the relationship between board composition and firm performance (Rose, 2005), development of the supervisory board (Koladkiewicz, 2001) and the independence of the supervisory board (Maassen \& Van den Bosch, 1999).

In one of the few empirical studies on supervisory boards in an Asia context, Dahya et al. (2003) examined the usefulness of the supervisory board of listed companies in China. Their research reported mixed results about the usefulness of the supervisory board. However, the supervisory board report was regarded by investors as a type of assurance and the absence of a supervisory board report could precipitate a drop in the share price because of investors' loss of confidence. In consequence, they argued that a supervisory board was a valuable mechanism within listed companies.

Dahya et al. ’s (2003) research also categorised supervisors into four groups: honored guest; friendly advisor; censored watchdog; and independent watchdog. Most supervisory boards were categorised one of the first three types. The 'honored guest' board was a board in name only, its establishment a mere formality. 'Friendly advisor' supervisors were dependent on directors or the CEO and performed almost no monitoring tasks. The 'censored watchdog' supervisors conducted their duties diligently. Listed companies that had 'independent-watchdog' supervisors were typically operating with foreign individuals/companies investments and supervisors strictly performed their monitoring duties. Xiao et al. (2004) generated these same four types of supervisors 
from 21 Chinese listed companies by using a grounded theory methodology. As directors are in a superior position to supervisors in China, Dahya et al. (2003) argued that supervisors need more power and should be more independent if organisations wanted them to perform a better job.

These empirical studies from the nonprofit and for-profit sectors highlight the various roles performed by directors and supervisors. The common roles ascribed to boards of directors centre on the establishment of direction for their organisations, including setting the mission/vision, and providing direct advice to management. In addition, the board of directors also perform resource roles, such as raising funds, and performance evaluation roles, such as evaluating management. On the other hand, boards of supervisors were mainly responsible for performing supervision roles, such as monitoring financial accounts. However, the very few empirical studies have been conducted with sport organisations, where both directors and supervisors are elected by organisational members. The aim of this research was to explore how the dual board system operates in Taiwanese sport organisations, and to investigate the respective roles of the board of directors and supervisors.

\section{Method}

Sample

All 70 organisations listed by The National Council of Physical Fitness and Sports, R.O.C. (Taiwan), according to Taiwan’s Civil Organisation Law, were contacted for participate in this study. These organisations were civil organisations, nation-level organisations, representing different sport disciplines and all had a dual board system. All respondents were guaranteed individual and organisational anonymity. Ultimately, 
board members from 24 organisations agreed to participate in this research.

Participation involved completing a survey questionnaire about board roles.

\section{Instrument}

The survey questionnaire used in this research was devised based on Inglis et al.’s (1999) framework of board roles. Inglis et al.’s framework was developed based on extensive reviews of board roles in nonprofit organisations and its validity and reliability had been confirmed and this research therefore utilized Inglis et al's framework as a foundation for board roles. However, their framework was primarily designed for a one-tier board system and the use of Inglis et al.’s framework may be questionable. To overcome this challenge, this research took the governance system of Taiwan into consideration.

The Civil Organisation Law of Taiwan (section 17, 23 and 29) legislates certain board processes, including electing executive board members, electing a board chairman, ratifying board members’ resignation and attending board meetings but it does not stipulate any other roles of directors and supervisors. Civil organisations, including nonprofit sport organisations, are expected to privately regulate these roles (Section 18). In order to contextualize the questionnaire items, four issues related to these processes were added. Data on the gender and age of respondents on the board were also collected to delineate the profile of respondents.

The questionnaire was initially written in English and then translated into Mandarin through backward and forward translations (Hayashi et al., 1992). A focus group interview was then conducted to assess content and clarity of the questionnaire and its application to the Taiwanese sport governance context. Two directors, two supervisors 
and two general secretaries from six different Taiwanese nonprofit sport organisations provided feedback. In the focus group interviews, interviewees argued that the questionnaire was mainly associated with the roles of directors and the questions of roles of supervisors should be asked by using another questionnaire or a separate section of questions. Modifications to the questionnaire were then made based on the interviewees’ comments and a number of additional questions related to the roles of supervisors were therefore developed. As a result, the focus group interview led to the development of two separate sets of questions, whereby members of boards of directors were asked to complete 21 questions and members of boards of supervisors were asked 10 questions.

A pilot study of the revised instrument was conducted with six current and previous board members and general secretaries of Taiwanese nonprofit sport organisations. The questionnaire worked well and only minor modifications were made to improve the wording and clarity of the questions. Participants of the focus group interviews and the pilot were not included in the final data collection phase.

\section{Procedures}

The revised questionnaire was distributed to directors and supervisors through the participating organisations between September 2006 and January 2007. A 5-point scale (1=Strongly Disagree) measured the degree the respondent fulfilled each role in their respective organisation. Within the 24 nonprofit sport organisations contained a total of 710 directors and 220 supervisors. Valid questionnaire responses were obtained from 158 directors (22.25\%) and 103 (46.82\%) supervisors. 
As the questionnaire developed for this study had not been tested with the target population, factor analysis was conducted to assess the underlying structure among the variables. As highlighted earlier, the dearth of reported research on Taiwanese board roles meant there was little precedent on the number of factors to be extracted from the analysis. Exploratory factor analysis was seen as appropriate (Hair et al., 2006) and the preferred sample size for factor analysis should be 100 or larger. The minimum sample size is to have at least 5 times as many participants as variables (Hair et al., 2006; Stevens, 2002). The number of variables of roles of directors and supervisors in this research were 21 and 10 respectively. Respective sample sizes of directors and supervisors in this present research were 158 and 103. The sample sizes were 7.5: 1 ratio of directors to variables and 10:1 ratio of supervisors to variables, which both fell within acceptable limits.

\section{Results}

Of the respondents, the majority of directors were male ( $n=148,93.7 \%)$, with only $6.3 \%$ female ( $n=10)$. Similarly, the majority of supervisors were male $(n=95,92.2 \%)$ with only $7.8 \%$ female supervisors $(n=8)$. The majority of directors and supervisors were over the age of 50 years (65.8 \% and $65.1 \%$ respectively). Chi-square analysis of gender $\left(\chi^{2}(1)=.201, \mathrm{p}=.654\right)$ and age $(\chi 2(1)=.017, \mathrm{p}=.898)$ found that there was no significant difference between directors and supervisors.

\section{Roles of directors}

Responses about the roles of directors, derived through a series of analyses, ultimately fell into four categories, each containing several roles. The conduct of a factor analysis was deemed appropriate (Field, 2005; Hair et al., 2006) as the value of KMO (.883) was 
in the acceptable range (greater than .5) and Bartlett's Test of Sphericity was highly significant $(\mathrm{p}<.001)$. Accordingly, the four factors whose eigenvalue over 1.0 were retained. Factor 1 explained $43.8 \%$ of total variance and together the 4 retained factors represented $67.2 \%$ of the variance of 21 variables. An oblique rotation (direct oblimin) was conducted to generate factor loadings which indicate the correlation between an original variable and its factor. A higher loading represents a strong relationship between variables. For interpretation purposes, we chose factor loadings with an absolute value of .40 or greater (Field, 2005; Pett, et al., 2003; Stevens, 2002). One variable failed to load significantly on any factors and it was eliminated (Pett et al., 2003). After deleting this single variable, 20 variables remained and the model was changed. Therefore, there was a need to re-calculate the factor loadings (Hair et al., 2006).

Table 1 describes the second round of the factor analysis of roles of directors. Four factors were again retained. The percentage explained by each of four factors was 43.3\%, 10.5\%, 7.9\% and 5.7\% percent respectively. All variables had factor loadings above .40. The highest correlation coefficient between factors was .560 therefore an oblique rotation was performed (Tabachnick \& Fidell, 2001).

$<$ Insert Table 1 about here $>$

The first factor, labelled as Manage Vision and Purpose, had eight roles—allocate the annual budget, formulate a vision, examine the annual plan, formulate a mission, examine the overall strategy, examine the financial policy, examine sport services provided to members/society, and respond to members/society needs. The focus was on 
roles regarding organisational direction and the purpose directors exist. In the second factor, Board Duty, directors performed three institutional duties: elect executive board members, elect the board chairman, and regularly attend the board meeting. The third factor, Human Resource and Fundraising, had seven roles including assigning work to the general secretary, evaluating the general secretary’s performance, hiring the general secretary, evaluating the board's performance, raising funds, ratifying decisions made by the general secretary in hiring paid staff and ratifying directors' resignation. The final factor, Stakeholder Focus, contained two roles with a focus on identifying and satisfying the needs of members and society; both are key stakeholders of nonprofit sport organisations (Blair, 1995; Clarke, 1998).

\section{Roles of supervisors}

The roles of supervisors were less diverse than the board of directors and ultimately were categorized into two areas. The analyses used the same assumptions as outlined above for the board of directors analysis. The value of KMO was .872 and results of the Bartlett's Test of Sphericity was significant $(\mathrm{p}<.001)$, therefore, conducting a factor analysis of roles of supervisors was also appropriate (Field, 2005; Hair et al., 2006). There were two factors having eigenvalues greater than 1 . Factor 1 explained $52.5 \%$ of total variance; Factor 2 accounted for $10.5 \%$ of total variance. The two factors represented $63.0 \%$ of the variance of 10 variables. Direct Oblimin rotation was again employed to rotate matrix and variables with a factor loading of .40 and above were considered. One variable had a cross loading on Factors 1 and 2. Kline (2000) suggested that because of difficulties in interpreting the scale, cross-loading variables should be eliminated. After deleting this one variable, nine variables remained and the model was 
changed. Therefore, there was a need to re-calculate the factor loadings (Hair et al., 2006).

Table 2 presents the second round of the factor analysis of roles of supervisors, where two factors were again retained. The percentage explained by each of two factors was $53.2 \%$ and $11.6 \%$ respectively. Variables all had factor loadings above .40 and cross loadings were not found. The correlation coefficient between two factors was .477.

$<$ Insert Table 2 about here $>$

The first factor, Monitoring Results, included five roles: review of annual budgets; supervise properly use of funds; final accounts review; supervisors’ resignation ratification; and major purchasing decision supervision. The second factor, Board Duty and Process, consisted of four roles: regular board meeting attendance; presentation of results of organisational performance at the general assembly; board meeting presentation of results of organisational performance; and election of executive supervisors.

The mean and standard deviation of the board roles from the sample of sport organisations are shown in Table 3. In general, the respondents means fall in the 3-4 range on the 5-point scale. The directors were relatively more focused on Board Duty; the supervisors were relatively more committed to Board Duty and Process. For the overall scale of roles of directors $\alpha=.93$. Within each of these scales, the $\alpha$ ranged from .66 to .91 . For the scale of roles of supervisors $\alpha=.89$. Within each of these scales, 
the $\alpha$ were .87 and .77 respectively. These coefficients were considered to be satisfactory (Hair et al., 2006).

$<$ Insert Table 3 about here $>$

\section{Discussion and conclusions}

This investigation of board roles in Taiwanese nonprofit sport organisations with a dual board system generated four factors for roles of directors and two factors for the roles of supervisors. The executive level leadership status of the board of directors/supervisors to the secretary department was evidenced through several board roles, namely, hiring the general secretary, assigning work to the general secretary, evaluating the general secretary’s performance, and supervising whether funds are used properly. Roles related to members/society and fundraising demonstrated that board members were expected to bring resources and serve as a conduit between their organisation and external environment. Several roles, such as electing the board chairman, attending board meetings and ratifying board members' resignation were also performed by both directors and supervisors.

The results demonstrate that board members conduct their roles as prescribed by Taiwan’s Civil Organisation Law. The secretary department enacts the initiatives taken in the director's board room that involve setting the organisation's vision, mission, strategy, policy and plan. The primary roles of the supervisory board were underpinned by the notion that funds should be monitored and reported on by an independent body that was not involved in raising or allocating revenue. 
Table 4 displays the comparisons between Inglis et al.'s (1999) framework and the board roles in the dual board system identified by this study. It is evident that there are some subtle differences in the roles of directors between the dual board system and onetier board systems. For example, in this dual board study assigning work to the general secretary was a role performed by directors, yet this was not found in Inglis et al.’s (1999) framework nor in previous sport governance research. Similarly, some operational roles of supervisors, such as supervising major purchasing decisions, were not found in Inglis et al.’s (1999) framework nor in previous for profit and/or nonprofit literature examining one-tier board systems.

$<$ Insert Table 4 about here $>$

Some of the roles of directors identified by this research were similar to roles found by previous studies of one-tier board systems, such as formulating a mission/vision (Cornforth, 2001; Dulewicz \& Herbert, 1999; Inglis et al., 1999); examining the overall strategy (Van den Heuvel et al., 2006); responding to member/society needs (Inglis et al., 1999); and evaluating the general secretary’s performance (Van den Heuvel et al., 2006). Certain roles of supervisors found in the current study, such as presenting results of organisational performance at the general assembly (Koladkiewicz, 2001), were also identified by previous research on dual board systems. In other words, some roles in the one-tier and two-tier board systems were common to the dual board system. However, this study has demonstrated that roles of board members in a one-tier board system are not wholly aligned with those in a dual board system. Additionally, the study has reinforced the benefits of a dual board system where the carriage of monitoring roles by 
a separate board, the board of supervisors, acts as a governance assurance mechanism. The dual board provides for the separation of supervision from management.

Moreover, the roles of directors and supervisors within the dual board system were different. Overall, the main role played by directors is to provide support and directions that assist their respective organisations to function; whereas supervisors are mostly involved in monitoring tasks. Compared to supervisors, directors work more closely with the secretary and executive departments. Most of the roles that supervisors perform centre on supervising the “team” formed by directors and the secretary’s department, in terms of supervising funds allocation. The supervisory board is not involved in managerial activities. The board of supervisors assumes the role of a "third party" in order to prevent becoming part of the team and to ensure they can supervise the team independently.

Raising funds is one of the roles performed by directors in nonprofit organisations. This role was, perhaps unsurprisingly, not found in for-profit organisations but has been identified in other nonprofit research (Iecovich, 2004; Inglis et al., 1999). In general, the mission of nonprofit sport organisations is to provide services to members/society at a low price or without any fee. In this context it is important for nonprofit board members to access and maintain financial resources.

Moreover, the factor analysis demonstrated that a director/supervisor plays a variety of roles in an organisation. For example, a director assumes a leadership role in formulating the organisation's vision/mission; setting the annual plan requires executive thinking; in assigning work to the general secretary director's assume management 
responsibility; evaluating the general secretary’s performance requires a performance management approach; regular attendance and contributions to board meetings to monitor performance against member expectations and strategic plans; and director's act as stewards for members and societal needs, and so on. A supervisory board member assumes the role of an assessor when they review the annual budget; the role of a monitor when supervising major purchasing decisions; and an organisational citizen through regularly attending board meetings and ensuring enduring organisational value.

In the dual board system directors and supervisors perform multiple roles in the organisation and fundamentally have different responsibilities. A director is expected to engage in a greater variety of roles than a supervisor, and a director should have an understanding of his/her roles, particularly the differences between a leader, examiner, manager, evaluator, organisational citizen and mediator. Three key roles, assessor, monitor and organisational citizen, are generally performed by supervisors. As such, a board director arguably has a relatively greater workload than a board of supervisors member although they are both volunteers and hold the same 'status' in the organisation.

These results can assist nonprofit sport organisations to understand the varied nature of board roles and to develop role descriptions for board members. In particular, this further elaboration of board roles can be used in decisions about recruiting and inducting new board members, and to identity candidates that can perform the varied roles required. An accurate role description will allow prospective board members to gain a clear perspective on the roles they would need to engage in, and from a selection viewpoint if the voting assembly know what is required of board members they can 
make better informed decisions about appropriate selection and election of board members.

The differentiation of tasks and roles identified in this paper can be used to inform the induction process of new board members, and to provide clarity on the roles they are expected to perform. For directors, this could entail highlighting the variety of board roles, particularly the attributes associated with being a leader, examiner, manager, evaluator, organisational citizen and mediator. For supervisors, three key roles, assessor, monitor and organisational citizen are relevant. During the research process it was identified that board training and provision of support material was minimal. Therefore, it is suggested that training workshops of returning and new board members could be arranged to help board members better understand their roles. A role description handbook that articulates each position and is made available to each board member would also be of benefit.

This research supports the argument that there is no one size-fits-all guideline of board roles. Many dimensions of governance, such as board systems, can have an impact on performance of board roles. If the most important spirit of performing board roles relies on the fundamental definition of governance to help an organisation run properly (Tricker, 1984), then it is incumbent on organisations to design board roles according to the requirements of the legislative or regulatory system to which they are bound, as well as the purpose and capacity of their organisation.

It should be noted that there were several limitations in this study. The participants in this research were drawn from 70 associations on the list of the National Council of 
Physical Fitness and Sports. Board members from 24 associations took part in this research, thus board members from the other 46 associations and other national sport associations were not included. Within the 24 associations, 158 directors (response rate $=20.7 \%$ ) were sent the first round questionnaire. While the sample size was sufficient for the statistical approaches employed by this research, the relatively low response rate may lead to a problem of generalization of the results to the national population of nonprofit sport associations. In addition, as the study participants were exclusively nonprofit sport organisations, the conclusions are not necessarily directly generalizable to other nonprofit organisations.

The dual board system maximises the possibility of fulfilling the many functions that a board is expected to perform. In dividing its functions amongst two boards the dual board creates a system in which each board is directly responsible for performing a subset of functions, with the monitoring component clearly distinguishable from the unitary board approach.

Future research should investigate the rationale for particular board composition and determine if this is related to board effectiveness. Moreover, results of this research could inform the government and the public of Taiwan about the governance practices employed by nonprofit sport organisations. Countries that intend to establish a dual board system could use these results as a basis on which to regulate their board's roles and further formulate role descriptions for boards. This study has shown that the dual board system is a dual protection system. Future research could also examine whether organisations with a dual board system have better performance outcomes than those with a single tier board system. 


\section{References}

Australian Sports Commission. (2002). National Sporting Organisations Governance: Principles of Best Practice. Canberra: Australian Sport Commission.

Australian Sports Commission (2005) Governing Sport. Canberra: Australian Sports Commission.

Bezemer, P.J., Maassen, G.F., Van den Bosch, F.A.J. \& Volberda, H.W. (2007) Investigating the Development of the Internal and External Service Tasks of Non- executive Directors: The Case of the Netherlands, Corporate Governance: An International Review, 15, 1119-1129.

Blair, M. M. (1995) Ownership and Control: Rethinking Corporate Governance for the Twenty-First Century. In Clarke T. (ed.) Theories of Corporate Governance. New York: Routledge.

Cadbury, A. (2002) Corporate Governance and Chairmanship: A Personal View. Oxford: Oxford University Press.

Carver, J. (1997) Boards That Make a Difference: A New Design for Leadership in Nonprofit and Public Organisations. San Francisco.: Jossey-Bass.

Chen, A., Kao, L., Tsao, M. \& Wu, C. (2007) Building a Corporate Governance Index from the Perspectives of Ownership and Leadership for Firms in Taiwan, Corporate Governance: An International Review, 15, 251-261.

Clarke, T. (1998) The Stakeholder Corporation: A Business Philosophy for The Information Age, Long Range Planning, 31, 182-194.

Cooke, T. E. \& Sawa, E. (1998) Corporate Governance Structure in Japan: Form and Reality, Corporate Governance: An International Review, 6, 217-223.

Cornforth, C. (2001) What Makes Boards Effective? An Examination of the Relationships between Board Inputs, Structures, Processes and Effectiveness in 
Nonprofit Organisations, Corporate Governance: An International Review, 9, 217-227.

Cornforth, C. \& Edwards, C. (1999) Board Roles in the Strategic Management of Nonprofit Organisations: Theory and Practice, Corporate Governance: An International Review, 7, 346-362.

Dahya, J., Karbhari, Y., Xiao, J.Z. \& Yang, M. (2003) The Usefulness of the Supervisory Board Report in China, Corporate Governance: An International Review, 11, 308-321.

Dulewicz, V. \& Herbert, P. (1999) The Priorities and Performance of Boards in UK Public Companies, Corporate Governance: An International Review, 7, 178-189. European Olympic Committee (2001) The Rules of the Game: Conference Report and Conclusion. Paper presented at the Europe's first conference on the Governance of Sport, Brussels.

Ferkins, L., Shilbury, D. \& McDonald, G. (2005) The Role of the Board in Building Strategic Capability: Toward an Integrated Model of Sport Governance Research. Sport Management Review, 8, 195-225.

Field, A. (2005) Discovering Statistics Using SPSS. London: SAGE.

Filatotchev, I., Lien, Y.C. \& Piesse, J. (2005) Corporate Governance and Performance in Publicly Listed, Family-Controlled Firms: Evidence from Taiwan, Asia Pacific Journal of Management, 22, 257-283.

Forster, J. (2006) Global Sports Organisations and Their Governance, Corporate Governance, 6, 72-83.

Hair, J. J. F., Black, W. C., Babin, B. J., Anderson, R. E. \& Tatham, R. L. (2006) Multivariate Data Analysis. NJ: Pearson. 
Hayashi, C., Suzuki, T. \& Sasaki, M. (1992) Data Analysis for Comparative Social Research: International Perspectives. Amsterdam: Elsevier Science Publishers B.V.

Houle, C. O. (1989) Governing Boards: Their Nature and Nurture. San Francisco: Jossey-Bass.

Hoye, R. (2006) Leadership within Australian Voluntary Sport Organisation Boards, Nonprofit Management and Leadership, 16, 297-313.

Hoye, R., \& Cuskelly, G. (2007). Sport Governance. Oxford: Elsevier ButterworthHeinemann.

Iecovich, E. (2004) Responsibilities and Roles of Boards in Nonprofit Organisations: the Israeli Case, Nonprofit Management and Leadership, 15, 5-24.

Inglis, S. (1997) Roles of the Board in Amateur Sport Organisations, Journal of Sport Management, 11, 160-176.

Inglis, S., Alexander, T. \& Weaver, L. (1999) Roles and Responsibilities of Community Nonprofit Boards, Nonprofit Management and Leadership, 10, 153.

Johnson, J. L., Ellstrand, A. E., \& Daily, C. M. (1996). Boards of directors: A review and research agenda. Journal of Management, 22(3), 409-438.

Jonsson, E.I. (2005) The Role Model of the Board: A Preliminary Study of the Roles of Icelandic Boards, Corporate Governance: An International Review, 13, 710-717.

Koladkiewicz, I. (2001) Building of a Corporate Governance System in Poland: Initial Experience, Corporate Governance: An International Review, 9, 228-237.

Kline, P. (2000) Handbook of psychological testing. London: Routledge.

Kula, V. (2005) The Impact of the Roles, Structure and Process of Boards on Firm Performance: Evidence from Turkey, Corporate Governance: An International Review, 13, 265-276. 
Lee, T.S. \& Yeh, Y.H. (2004) Corporate Governance and Financial Distress: Evidence from Taiwan, Corporate Governance: An International Review, 12, 378-388.

Long, T., Dulewicz, V. \& Gay, K. (2005) The Role of the Non-executive Director: Findings of an Empirical Investigation into the Differences between Listed and Unlisted UK Boards, Corporate Governance: An International Review, 13, 667679.

Maassen, G. F., \& Van den Bosch, F. A. J. (1999) On the Supposed Independence of Two-Tier Boards: Formal Structure and Reality in the Netherlands, Corporate Governance: An International Review, 7, 31-37.

McNulty, T. \& Pettigrew, A. (1999) Strategists on the Board, Organisation Studies, 20, 47-74.

Nietsch, M. (2005) Corporate Governance and Company Law Reform: A German Perspective, Corporate Governance: An International Review, 13, 368-376.

Pett, M. A., Lackey, N. R. \& Sullivan, J. J. (2003) Making Sense of Factor Analysis. Thousand Oaks: SAGE Publications.

Pointer, D. D. \& Orlikoff, J. E. (2002) The High-Performance Board: Principles of Nonprofit Organisation Governance. San Francisco: Jossey-Bass.

Rose, C. (2005) The Composition of Semi-Two-Tier Corporate Boards and Firm Performance, Corporate Governance: An International Review, 13, 691-701.

Schilling, F. (2001) Corporate Governance in Germany: the Move to Shareholder Value, Corporate Governance: An International Review, 9, 148-151.

Shilbury, D. (2001) Examining Board Member Roles, Functions and Influence: A Study of Victorian Sporting Organisations, International Journal of Sport Management, 2, 253-281. 
Solomon, J.F., Lin, S.W., Norton, S.D. \& Solomon, A. (2003) Corporate Governance in Taiwan Empirical Evidence from Taiwanese Company Directors, Corporate Governance: An International Review, 11, 235-248.

Sport and Recreation New Zealand. (2004). Nine steps to effective governance: Building high performing organisations. Wellington, New Zealand: Sport and Recreation New Zealand.

Sport and Recreation New Zealand. (2007). Nine steps to effective governance: Building high performing organisations. ( ${ }^{\text {nd }}$ ed.) Wellington, New Zealand: Sport and Recreation New Zealand.

Stevens, J. (2002) Applied Multivariate Statistics for the Social Science. NJ: Lawernce Erlbaum Associates, Publishers.

Tabachnick, B. C. \& Fidell, L. S. (2001) Using Multivariate Statistics. Boston: Allyn and Bacon.

Tricker, R. I. (1984) Corporate Governance. London: Gower.

Turnbull, S. (1997) Corporate Governance: Its Scope, Concerns and Theories, Corporate Governance: An International Review, 5, 180-205.

UK Sport. (2004). Good governance guide for national governing bodies. London: UK Sport.

Van den Heuvel, J., Gils, A.V. \& Voordeckers, W. (2006) Board Roles in Small and Medium-Sized Family Businesses: Performance and Importance, Corporate Governance: An International Review, 14, 467-485.

Xiao, J.Z., Dahya, J. \& Lin, Z. (2004) A Grounded Theory Exposition of the Role of the Supervisory Board in China, British Journal of Management, 15, 39-55. 
Yeh, Y.H. \& Woidtke, T. (2005) Commitment or Entrenchment? Controlling Shareholders and Board Composition, Journal of Banking \& Finance, 29, 18571885.

Zahra, S.A. \& Pearce, J.A. (1989) Boards of Directors and Corporate Financial Performance: A Review and Integrative Model, Journal of Management, 15, 291. 
Figure 1 Structure of a dual board system

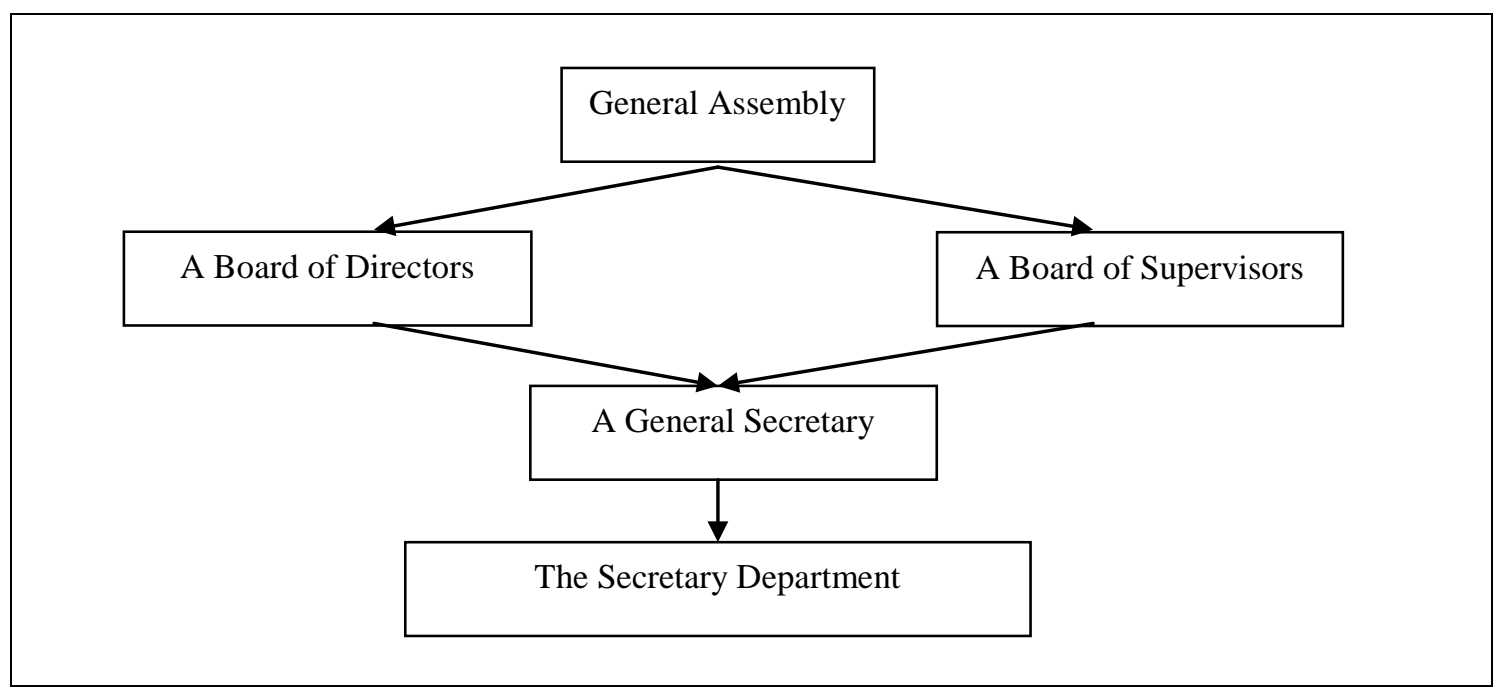


Table 1 Factor Matrix for Roles of Directors

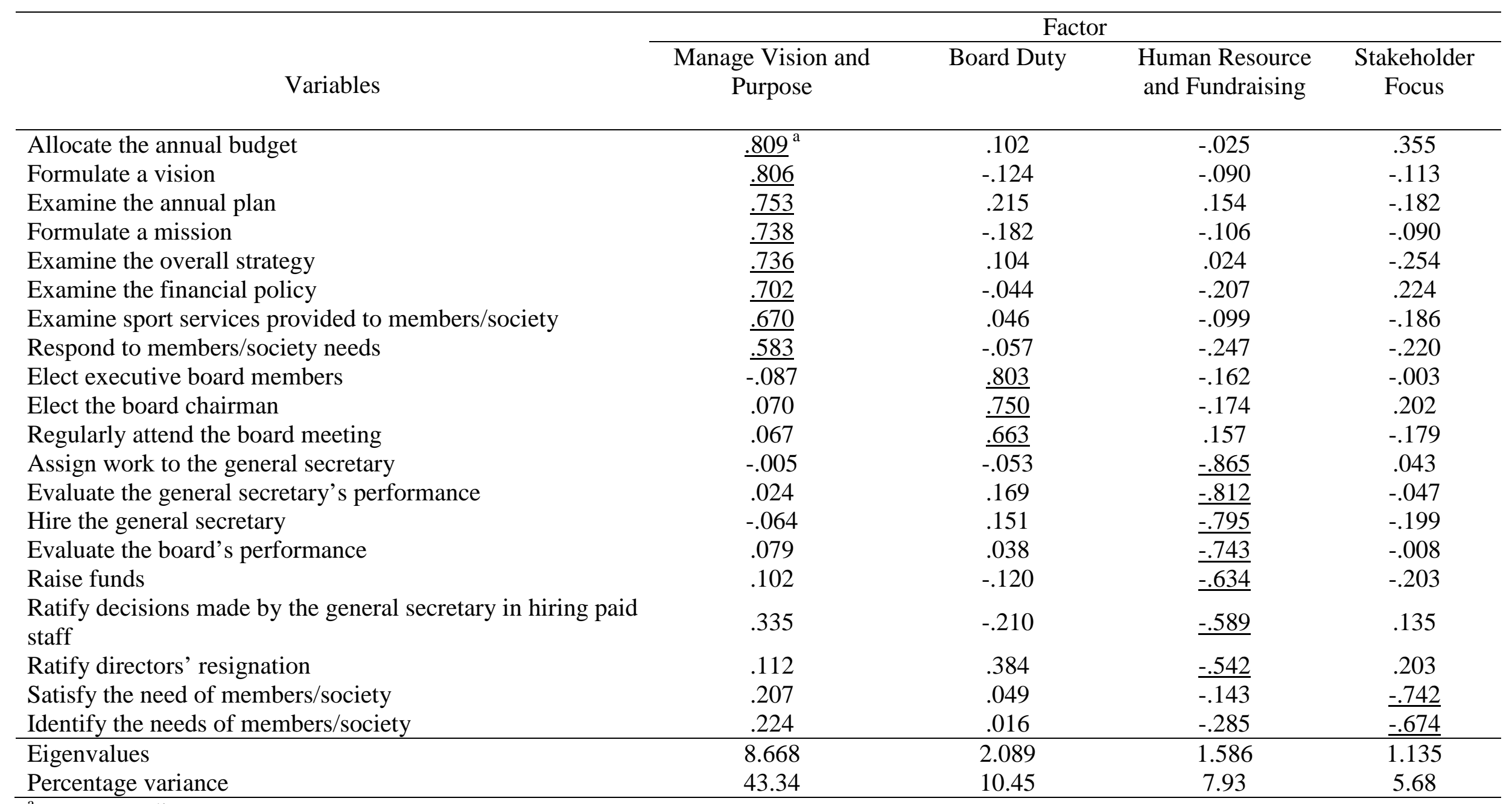

${ }^{\mathrm{a}}$ Factor Loading 
Table 2 Factor Matrix for Roles of Supervisors

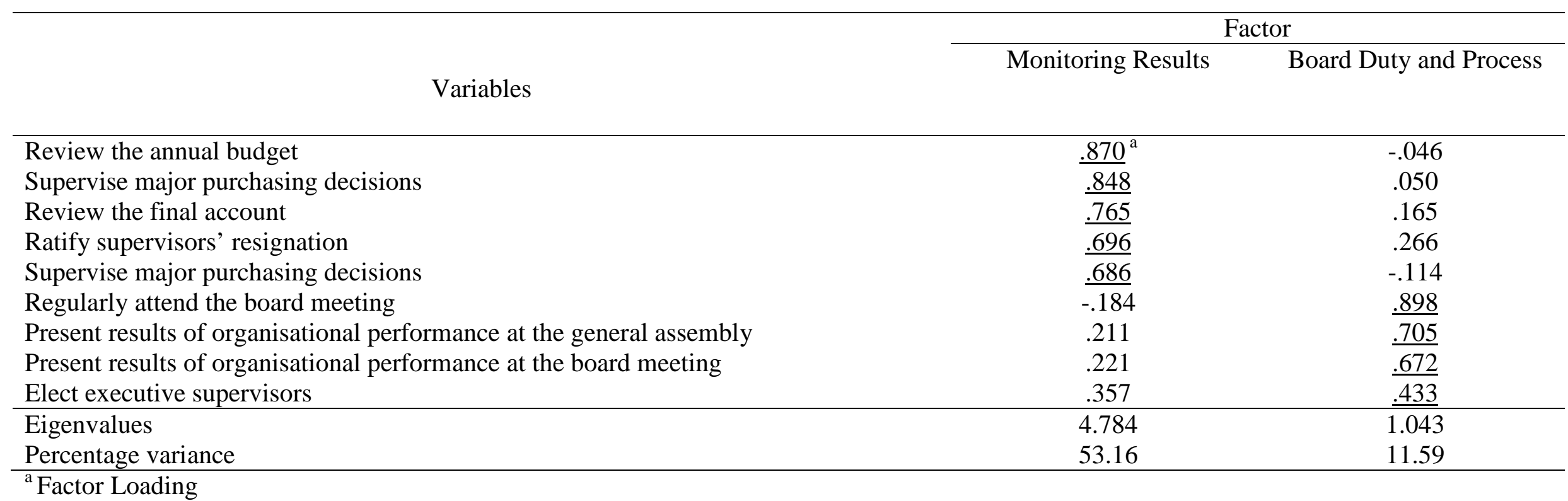


Table 3 Descriptive Statistics and Reliability for Board Roles

\begin{tabular}{cccc}
\multicolumn{1}{c}{ Board roles } & Mean & $\begin{array}{c}\text { Standard } \\
\text { deviation }\end{array}$ & $\begin{array}{c}\text { Reliability } \\
\text { Coefficient }\end{array}$ \\
\hline Roles of directors & 3.68 & .78 & .93 \\
Manage Vision and Purpose & 4.35 & .69 & .91 \\
Board Duty & 3.13 & .86 & .89 \\
Human Resource and Fundraising & 3.80 & .85 & .82 \\
Stakeholder Focus & & & .89 \\
Roles of supervisors & 3.94 & .70 & .87 \\
Monitoring Results & & .66 & .77 \\
Board Duty and Process & 4.25 & & \\
\hline
\end{tabular}


Table 4 Comparisons of board roles between Inglis et al.’s framework and a dual board system

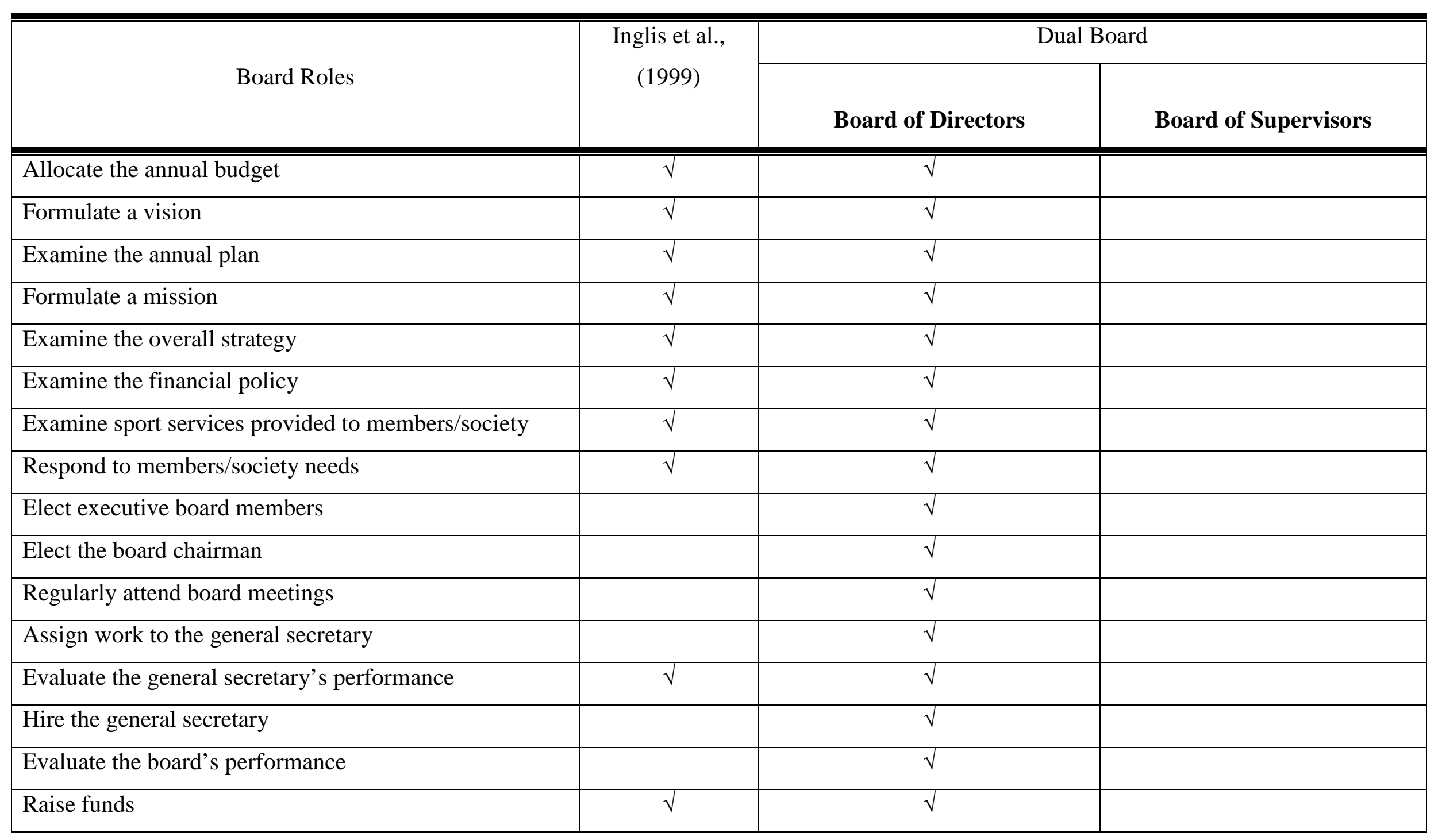




\begin{tabular}{|c|c|c|c|}
\hline $\begin{array}{l}\text { Ratify decisions made by the general secretary in hiring } \\
\text { paid staff }\end{array}$ & $\sqrt{ }$ & $\sqrt{ }$ & \\
\hline Satisfy the needs of members/society & $\sqrt{1}$ & $\sqrt{ }$ & \\
\hline Identify the needs of members/society & & $\sqrt{ }$ & \\
\hline Liaison Role & & $\sqrt{ }$ & \\
\hline Supervise whether funds are used properly & & & $\sqrt{ }$ \\
\hline Review the final account & & & $\sqrt{ }$ \\
\hline Ratify supervisors’ resignations & & & $\sqrt{ }$ \\
\hline Supervise major purchasing decisions & & & $\sqrt{ }$ \\
\hline $\begin{array}{l}\text { Present results of organisational performance at the } \\
\text { board meeting }\end{array}$ & & & $\sqrt{ }$ \\
\hline Elect executive supervisors & & & $\sqrt{ }$ \\
\hline Oversee the progress of the annual plan & & & $\sqrt{ }$ \\
\hline Ensure regulation abidance & & & $\sqrt{ }$ \\
\hline Deliver specific programs and services & $\sqrt{ }$ & & \\
\hline
\end{tabular}

